\title{
Albanian Foreign Policy Relations with United States of America after the Cold War
}

\author{
Anton Bardhaj, PhD student \\ University of Tetova, North Macedonia
}

\begin{abstract}
This paper aims to address Albanian foreign policy relations with the US after the Cold War by using the methods of analysis and synthesis, generalization and specialization as well as methods of compilation and description, also including the method of comparison. From the process of state formation, Albania has faced various problems with regard to consolidation and institutionalization in the domestic sphere as well as threats and instability at regional and international level. Albania's self-imposed isolation shut the country down from international trends, and this trend continued to the bitter end of the communist regime in Albania in the early 1990s. Albania began the transition of the communist regime following other precedents in Central and Eastern Europe. Despite the limited relaxation of the country's isolation following Enver Hoxha's death in 1985, this did not prevent Albania from being the last communist regime in Europe to begin its transformation. This marked the return of Albania to the international scene after a long period of isolation. Integration into the international system and the development of relations with other countries were key priorities for Albania's new foreign policy orientation. In the context of Albania's struggle for a stable state, Albanians attribute considerable respect to the USA and, in particular, to President Woodrow Wilson whom Albanians regard as the basis for securing Albania's existence as a state because in the 1919s-1920 Wilson strongly argued against a proposed separation of Albania from the Paris Conference and thereafter enabling Albania to achieve statehood and international recognition by the League of Nations. This therefore constitutes the main aim of this paper.
\end{abstract}

Keywords: Albanian foreign policy, US foreign policy, alliance, international relations, pro-Americanism 


\section{Introduction}

In the late 1970s, Albania embarked on a policy of rigid self-reliance. By removing ties with the main communist states, Albania sought total economic independence and declared itself as the only authentic MarxistLeninist state in the world. Indeed, the government was forbidden to seek foreign aid and credit or to motivate foreign investment in the country. Enver Hoxha adhered to Marxism-Leninism, seeing the world divided into two opposing systems-socialism and capitalism. But, he also led Albania in a twofront war against both the US "imperialism" and the Soviet "socialimperialism". For example, Albania refused to participate in CSCE talks or sign the Helsinki Accords in 1975 because the United States and the Soviet Union had initiated the negotiating process (Zickel and Walter, 1994).

When US President George W. Bush began his brief eight-hour visit to Albania on June 10, 2007, neither world public opinion nor himself, despite earlier reports, were expecting a so massive welcome and support by the Albanians and the Albanian state, which was perceived as a very positive thing by the Americans at least to get a positive local response at a time of declining US public support in the eyes of world opinion. The Albanians were displaying support for world superpower in their country and a sign of Albania's importance to the United States, as they were proud to be perhaps the leading pro-American country in the world.

After the Cold War, Albania declared integration into Euro-Atlantic structures as the main national aim of its international policy. In this regard, Albania as a "small power" declared its objective to develop preferred relationships with the US, as a "great power", as the most trusted ally and sole superpower enjoying the support of Albania's political elite and the Albanian nation in general. In order to maintain this unique bilateral strategic relationship, Albania has always sought to offer its full support for US foreign policy goals in the Balkans and on the international scene.

The creation and development of strategic Albania-US relations after the Cold War can be elaborated within a time frame that includes three distinct periods, namely:

-Creation of special strategic relationships in 1991-1998;

-Strengthening strategic relations in 1999-2001, and

-Transforming strategic relationships into an alliance in 2001 and beyond.

\section{Creation of special strategic relationships in 1991-1998}

The United States established diplomatic relations with Albania in 1922, following its independence in 1912 from the Ottoman Empire. American diplomatic relations broke down in v. 1939 due to the occupation of Albania by Italy (until 1943) and Germany (until 1944) during the Second 
World War. After this war, Albania experienced forty years of isolation under its communist leadership. With the collapse of communism in 1991, the Albanian government sought closer ties with the West in order to improve economic conditions and initiate fundamental democratic reforms.

On March 15, 1991, the US restored diplomatic relations with Albania. The visit of US Secretary of State James Baker to Albania on July 31, 1991 was another important factor in this relationship, namely the advocacy of the Albanian public for the USA. James Baker's extraordinary reception in Tirana proved that communist propaganda to create the image of the US as an enemy of the Albanians had proved false, while the US was perceived by public opinion as the country embodying the aspiration of the Albanians for democracy and progress as well as the defender of Albanian interests in a destabilized area and fragile economic situation in the state. After a long period of communist isolationist diplomacy, Albania returned to the regional and international scene as the US opened the Embassy on October 1, 1991, with William Edwin Ryerson being the first US ambassador to Albania after 52 years. He made a very important contribution to supporting the new opposition that came to power on March 31, 1991 (Arvizu, 2011, p.1).

The intensified conflict in Bosnia and Herzegovina and Croatia in 1993 made the US and other Western powers interested in making Albania a country that did not support the armed military rebellion of Albanians in Kosovo and Macedonia, so in return of Albania's support for maintaining the status quo in the Balkans, the US was providing economic and political support. Furthermore, Albania aimed to develop a special relationship with the US, especially in the field of security. Albania signed the Memorandum of Understanding on Military Relations with US in October 1993, the first of its kind with a ex-communist state, establishing US military relations with Albania (Meksi, 2003, p. 21), which was considered by the US as an extension of US military positions in the Balkan region (Perretti, 2000, p. 37).

Albanian-American relations reached their peak during the bombing period in Bosnia and Herzegovina, while Albania provided the assets needed to meet all US and NATO needs in terms of military engagement. Despite the excellent relationships among two countries, the Kosovo issue did not become part of the conflict resolution. This is because of the complicated security equation in Bosnia and Herzegovina, which was endangered by an additional conflict variable thus defining the boundary of this strategic relationship.

Former U.S. President George H.W. Bush hosted a meeting with President Berisha in 1992, and former President Bill Clinton also, met with him at the White House in 1995. At this meeting between Berisha and Clinton, the importance of Tirana in the Balkans over US-Albanian relations was emphasized. Clinton praised Berisha's responsible approach to ethnic Albanians in the former Yugoslavia for supporting Kosovo's autonomy. 
During this visit, Berisha proposed to the US the use of military bases in Albania. These relations among Albania and the US had a positive reflection on the Albanian national cause. It was seen in March 1998 when the US participated in the Kosovo war, where the issue of Kosovo did not only affect US policy in the Balkan region, but also the changes that took place in the structure of the international system, especially with the US military intervention in Kosovo without any UN Security Council decision (Biberaj, 1999, p. 230-234).

\section{Strengthening strategic relations in 1999-2001}

Later, when the Kosovo conflict broke out due to the failure to address this issue in the Dayton peace process, Albania became important again with its assistance to NATO intervention. Throughout the conflict, Albania, in line with US recommendations and in part due to its lack of capacity, was not included in military intervention and was thus not a party to this military conflict. Albania followed this line of foreign policy, being careful and cooperative on the Albanian issue that also concerns the Albanians of North Macedonia. Albanian sympathy and confidence in the United States increased sharply after NATO intervention in Kosovo. In this process, the United States was perceived as a main player in planning and implementing military intervention to save Albanians. Compared to Europeans' previous pressing record during the civil war in Bosnia and Herzegovina and their inability to stop humanitarian catastrophes, US engagement in inter-military military conflicts in the Balkans has had a major impact on Albania's strengthening of strategic relations with the US, in order to get support for its international policy in the Balkan region. NATO's military campaign in Kosovo and the subsequent creation of a protectorate in Kosovo by the United Nations reinforced the US image as the country that enjoys the greatest trust of all Albanians in the Balkan region (Philips, 2005, p. 309-330).

\section{Transforming strategic relationships into an alliance in 2001 and beyond}

The September 11, 2001, terror attacks on the United States changed US foreign policy priorities by focusing them on the "War on Terror." Europe was divided on its stance on military intervention in Iraq, while Albania was among the eight European states to declare its support against Saddam Hussein's regime and send troops to Iraq after approval by the Albanian Parliament on March 13, 2003 (U.S. Department of Defense, 2002).

The contribution of Albanian troops exceeded the limited quantitative participation, as this support was of particular value to the US given the secular nature of the Albanian state and the fact that Albania as a Muslim-majority country was strongly supporting the US. In this context, Albania offered its 
long experience of religious harmony for help that would later be increasingly in the American interest, as the United States had a Muslim-majority state with sympathy for them.

With US support, in May 2003, NATO Partner countries: Albania, Croatia and North Macedonia signed "Adriatic Charter" which constitutes a military partnership as well as a clear sign of US support for these countries in line with open door policy (Gredešič, 2004).

Albania signed Bilateral Agreement with US in 2003, to exclude citizens of both parties from the obligation to submit them to the International Tribunal of Justice, which was criticized by EU officials and strongly supported by all Albanian political parties (Erzeni, 2003).

Albanian Captain Vogli lost his life in office in 2012 during a joint military operation by Albanian and US special forces in Kandahar, Afghanistan. Albania became one of the leading small states providing full diplomatic and military support for the American-led official position in the war versus Iraq and in a way that helped justify this position in the international arena (Fawn, 2006).

The Albanian government saw this support as reflecting Albania's transformation into a security-consuming nation to contribute to global security and international initiatives (Aaron, 2005).

In this process, Albanian Prime Minister Nano wrote two consecutive letters published in the "Boston Globe" and: "The Wall Street Journal" highlighting the US role in liberating Europe during the Second World War and in the NATO campaigns in Kosovo, thus drawing parallels with the need to get rid of Saddam Hussein's regime in Iraq, just like the Nazis or Slobodan Miloševič (Nano, 2003).

Albania had already sent a fifth round of military forces to Afghanistan to contribute to training the Afghan police forces. Albania is currently a strong supporter of the United States and participates in the Coalition Operations in Iraq, while increasing its contribution to Afghanistan, as all of these developments have helped build a loyal bilateral alliance among the United States and Albania.

Regarding Albania's contribution to building an alliance with the US, the trade between two countries and on belonging to a number of the identical international organizations, at the US Department of State's official Web site, is noted that: "Albania has contributed to regional and global security. Albanians appreciate NATO's 1999 intervention against the former Federal Republic of Yugoslavia with the rescue of thousands and thousands of Kosovo Albanians in support of UN mediation engagements in Kosovo. Albania has supported US policy of expanding the number of states for diplomatic recognition of Kosovo. Under the Adriatic Charter, Albania has acted as a leader to the new NATO aspirants. It has provided troops for US-led actions 
in Afghanistan and Iraq and supported US versus terrorism efforts by contributing to the Global Coalition to combat ISIS, freezing terrorist assets, shutting down civil organizations with potential links to funding terrorism and the exclusion of extremists. Trade with the United States accounts for a small part of Albania's trade volume, and is focused on a narrow range of goods and services. Major imports from the United States include food, cars, machinery and computer and electronic tools, while the main exports to the United States include minerals, petroleum products, as well as agricultural and textile products. Albania is eligible to export certain products duty-free to the United States under the Generalized System of Preferences program. The United States and Albania have signed a bilateral investment treaty. Albania and the United States belong to a number of the identical international organizations, including the UN, NATO, Euro-Atlantic Partnership Council, OSCE, IMF, WB, and WTO. Albania also is an observer to the Organization of American States. From June 2014, Albania is a candidate for accession into the EU. (US Department of State, 2019).

Pro-American sentiment is powerful and quite extended among the Albanian population (Lucas, 2007). Despite the fact that the United States, which had closed its mission in Albania in 1946, was being labeled by Communist propaganda during Hoxha's regime, however, most Albanians remembered that U.S. President Wilson had mediated with a strong commitment in the name of Albanian independence from 1919 to 1920 , vigorously engaging against a proposed partition of Albania by the Paris Conference and subsequently enabling Albania to achieve statehood and international recognition by the League of Nations (Zickel and Walter, 1994). According to the 2012 U.S. Global Leadership Report, 80\% of Albanians approve of U.S. leadership, the second-highest rating for any surveyed country in Europe after the partially recognized Kosovo (US Global Leadership Project Report, 2012).

Albania has supported the U.S. in the Global War on Terror by freezing terrorist finance, shutting down civil organizations with possible links to Terrorist financing, expelling extremists, and providing military and international advocacy for the U.S. led actions in Afghanistan and Iraq, Albania has played a moderating role in the region and has fully supported UN mediation efforts in Kosovo. Albania also has six hundred elite soldiers deployed in Afghanistan as part of the International Security Assistance Force, and 240 troops as part of Multi National Force in Iraq (US Global Leadership Project Report, 2012).

In 2011, the President of the Republic of Albania, Bamir Topi, through a message delivered to U.S. President Barack Obama, elaborated the elimination of Osama Bin Laden, considering it as one of the greatest victories in the war against international terror: "Let me congratulate you on 
accomplishing the mission of restoring justice, with the elimination of Osama Bin Laden by US forces, thus achieving one of the most significant victories in the long and difficult fight against international terror! As President of the Republic of Albania nn behalf of the Albanians, I would like to express my most sincere congratulations on the achievement of this significant goal that pleased me and at the same time made me proud that my country was lined up by Albania's greatest ally and friend: United States of America, the country that believed in uncompromising war against evil, against terror, defending the sacred principles of freedom and democracy throughout the Earth, as well as ensuring security, peace and stability in all parts of the world. Let me, Mr. President, on behalf of the Albanian people and in my personal name, once again express my best wishes for this great victory and at the same time to assure you that Albania will continue to fulfill with its most sincere commitment its obligations towards NATO, contributing to future challenges to freedom, democracy, and building a better world for nations and their future" (Likmeta, 2011).

\section{Conclusion}

In the post-Cold War era, Albania again sought to turn its geopolitical weakness and position to advantage by adopting policies in line with developed Western approaches. In doing so, Albania had to balance its traditional alignment policy with a great power by developing broad bilateral relations and broad ambitions to be part of integrated Europe. In this process, Albania has particularly sought to forge a close relationship that would be closer to an alliance with the US, making it an indispensable pillar of its international policy. Albania has succeeded in receiving US support in economic affairs and, more importantly, in developments related to Albanians in other regions of the Balkans. In return, Albania provided as much support as possible within its capacity for US policy on the international scene.

In this paper, it was concluded that, successive US administrations have expressed strong support for Albania's political and economic transition and its Euro-Atlantic integration aspirations, including NATO membership. Until March 15, 1991, there were no significant international diplomatic relations between Albania and the United States. At the end of the Cold War, Albania established and developed its international relations on the international stage. Within this differentiated policy report, three different dimensions can be ascertained:

- Albania switched from communist regime to democratic regime;

- After the end of the Cold War and the breakup of the former Yugoslavia, the "Albanian issue" became more dynamic than it was before. In this regard, the US is Albania's strategic partner; and 
- The establishment of Albania-US relations has geopolitically and positively affected the region. After the creation of the Berisha Government (1991), Albania's foreign policy and its democratization process were supported by the US. In the early 1990s, it was unlikely that any other European country with the same willingness as Albania to establish good strategic international relations with the United States of America.

\section{References:}

1. Arvizu A, Alexander, (2011) US-American Relations, Building the Future, Tirana

2. Biberaj, Elez (1999), Albania in Transition: The Rocky Road to Democracy, Oxford

3. Erzeni, Orest, (2003) "ICC Agreement Wins Strong Support for Albanian Political Parties", Southeast European Times

4. Fawn, Rick, (2006), "Alliance Behaviour, the Absentee Liberator and the Influence on Soft Power: Post-communist State Positions over the Iraq War in 2003", Cambridge Review of International Affairs, vol. 19

5. U.S. Department of Defense (2002), Fact Sheet, Office of Public Affairs, "International Contributions to the War against Terrorism", Washington D.C.

6. Gredešič, Ivan, (2004), "US-Adriatic Charter Partnership: Securing the NATO Open Door Policy", Politička Misao, vol. 41, Zagreb

7. Klein, Aaron, (2005), "Albania ready to join "International Community": Prime Minister Talks of Troops in Iraq, fighting alQaida and EU Membership", WorldNetDaily

8. Likmeta, Besar (2011), "Albania Leaders Praise US for Bin Laden Assassination”, BalkanInsight, Tirana, May 2, 2011

9. Meksi Ermelinda, (2003) "The Albanian Dimension of Integration", Albanian Institute for International Studies, Tirana

10. Nano, Fatos, (2003), "A Salute to Brave American Spirit", The Boston Globe, 9 February 2003;\&Nano, Fatos, 2003, "Letters to the Editor: The Silent Witnesses of the Normandy Beach", The Wall Street Journal

11. Perretti Michel, (2000), "The Stability Pact and Its Role in Albania's Road towards Integration with the European Union", Albanian Institute for International Studies, Tirana

12. Philips, David L., (2005), "Albania", American Foreign Policy Interests, vol. 27

13. Peter Lucas (2007), Why Albanians love America, New York Times, June 14, 2007 
14. Raymond Zickel\&Walter R. Iwaskiw (1994) Albania: A Country Study. Washington: GPO for the Library of Congress

15. US Department of State, https://www.state.gov/u-s-relations-withalbania/, Accessed December 2, 2019

16. U.S. Global Leadership Project Report, 2012 